\title{
Reflections on the Past, Present, AND Future OF RESTORATIVE JUSTICE IN CANADA
}

\author{
BARBARA TOMPOROWSKI, ${ }^{*}$ MANON BUCK, ${ }^{* *}$ \\ CATHERINE BARGEN, ${ }^{* * *}$ AND VALARIE BINDER ${ }^{* * * *}$
}

\begin{abstract}
Restorative justice has been integrated into the Canadian justice system for over 30 years and it is now appropriate to acknowledge the achievements of the past, reflect on its current status, and consider where it may go in the future. Restorative justice evolved from experimentation by justice officials and community members looking for better ways to respond to crime, and there is a great deal of variation in how it is defined, understood, and practised. Provisions of the Criminal Code and the Youth Criminal Justice Act support the use of restorative justice in the criminal context. While restorative justice is being used across Canada and there are signs that it is maturing, there are also a number of challenges it faces, such as the need for ongoing funding and national data collection, and the need to define its relationship with Aboriginal justice and continue to engage victim service agencies. However, with continued leadership and support from community-based agencies, Aboriginal groups, faith organizations, governments, universities, and justice agencies, restorative justice will continue to evolve and expand in Canada.
\end{abstract}

La justice réparatrice a été intégrée dans le système de justice canadien il y a plus de 30 ans, et l'on peut maintenant confirmer les réalisations du passé, réfléchir à l'état actuel et envisager où cela peut mener à l'avenir. La justice réparatrice a évolué à partir d'essais de représentants du milieu de la justice et de membres de la communauté à la recherche de meilleures manières de réagir aux activités criminelles; il y a de grandes différences dans la manière de définir, de comprendre et d'appliquer cette forme de justice. Les dispositions du Code criminel et de la Loi sur le système de justice pénale pour les adolescents appuient le recours à la justice réparatrice dans le contexte criminel. Bien que la justice réparatrice soit utilisée dans l'ensemble du Canada et qu'elle manifeste des signes de maturité, elle fait face à beaucoup de difficultés, comme le besoin de financement continu et de collecte de données nationales ainsi que le besoin de définir sa relation avec la justice autochtone. Elle doit aussi continuer à faire appel aux organismes de services d'aide aux victimes. Cependant, avec une bonne direction et un bon soutien des organismes communautaires, les groupes autochtones, les organismes religieux, les gouvernements, les universités et les organismes de justice, la justice réparatrice continue d'évoluer et de prendre de l'expansion au Canada.

\section{TABLE OF CONTENTS}

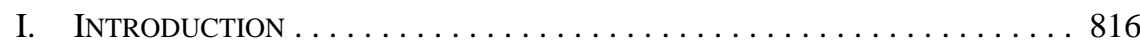

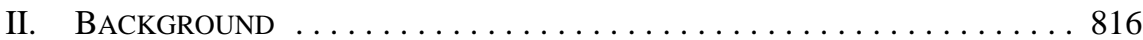

* $\quad$ Senior Policy Analyst, Saskatchewan Ministry of Justice and Attorney General; Co-Chair, FederalProvincial-Territorial Working Group on Restorative Justice; Sessional Lecturer, Department of Justice Studies, University of Regina. She works and volunteers with restorative justice initiatives at the local, provincial, and national levels, such as the Steering Committee for the Canadian Restorative Justice Consortium.

** Restorative Justice Division, Correctional Service Canada. Formerly, she worked as a Conflict Resolution Advisor for Canada Revenue Agency where she coached and mediated employees in conflict. She has also volunteered with YOUCAN, promoting and facilitating non-violent conflict resolution in schools and communities, and now volunteers for the Collaborative Justice Program, facilitating victimoffender mediation at the Ottawa Provincial Courthouse.

*** $\quad$ M.A. (Conflict Transformation), Center for Justice and Peacebuilding, Eastern Mennonite University; Restorative Justice Coordinator, British Columbia Ministry of Public Safety and Solicitor General. Formerly, she was on staff with Langley, British Columbia's Community Justice Initiatives Association and is the author of Educating for Peacebuilding: Implementing Restorative Justice Principles and Practices in a School System (Langley: Community Justice Initiatives Association, 2010).

**** Coordinator, Restorative Community Conference Program for Youth Justice, Health and Social Services, Yukon Government. As a practitioner and instructor in restorative community conferences, she has contributed to and influenced the development of restorative practices throughout Yukon and some parts of Alaska. She has presented on restorative justice at national and international conferences, for First Nation Governments, and as a guest lecturer at the University of Alaska, Fairbanks. 
$\begin{array}{lll}\text { A. Common Restorative Justice Processes } \ldots \ldots \ldots \ldots \ldots \ldots & \ldots 17 \\ \text { B. Restorative Justice in LAW And Policy } \ldots \ldots \ldots \ldots & \ldots \ldots \ldots 19\end{array}$

III. ThE PAST, PRESENT, AND FUTURE OF

RESTORATIVE JUSTICE IN CANADA . . . . . . . . . . . . . . . . . . . . . . 821

A. The EVOlution of Restorative Justice . . . . . . . . . . . . . . 821

B. The StATUS OF Restorative JUSTICE

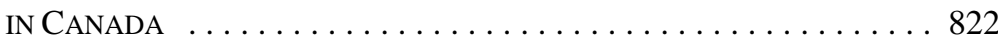

C. Challenges Facing Restorative Justice

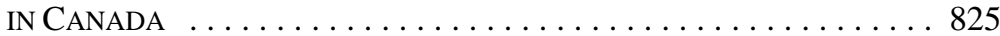

IV. REFLECTIONS ON THE FUTURE AND CONCLUSIONS . . . . . . . . . . . 828

\section{INTRODUCTION}

National Restorative Justice Week originated in Canada in 1996, and is now celebrated in at least 18 countries during the third week of November. ${ }^{1}$ The Canadian theme for National Restorative Justice Week 2010 was "Reflexions Past, Present and Future." As restorative justice "has been incorporated in the formal justice system for over 30 years," this is an appropriate time to acknowledge the achievements of the past, reflect on the current status of restorative justice, and consider where it may go in the future.

Restorative justice is used in many sectors. It is growing rapidly in the education system in Canada and other countries, ${ }^{3}$ has been used to address cases of abuse and neglect in the child welfare system, ${ }^{4}$ and is being used in fish and wildlife conservation cases in places such as British Columbia. ${ }^{5}$ This article, however, focuses on restorative justice in the criminal justice system. It begins by defining restorative justice in the criminal justice context, discussing how it is supported by legislation and policy, and describing commonly used restorative justice processes. This leads to a consideration of the past, present, and future of restorative justice in Canada, including its evolution, current status, and challenges. Finally, this article presents some conclusions and reflections about the future of restorative justice.

\section{BACKGROUND}

Restorative justice began in the 1970 s as a grassroots, community-based movement. There are at least four streams that contributed to its development. ${ }^{6}$ These streams include approaches based on the practices of Indigenous people in Canada and around the world, the

Correctional Service of Canada, Restorative Justice Week 2009: National Report (Ottawa: Correctional Service of Canada, 2009) at 3, online: Correctional Service of Canada <http://www.csc-scc.gc.ca/text/rj/ rj2009/rep09-eng.pdf> [Restorative Justice Week 2009].

2 Federal-Provincial-Territorial Working Group on Restorative Justice, "Key Messages on Restorative Justice,” online: Correctional Service of Canada <http://www.csc-scc.gc.ca/text/rj/rprts/keymsg-eng. shtml>

3 Marg Armstrong, "Restorative Justice: An International Perspective" (Presentation at Restorative Practices in Schools: The Way Forward, Melbourne, 20 October 2009) [unpublished].

4 Gale Burford \& Joan Pennell, Family Group Decision Making: New Roles for "Old” Partners in Resolving Family Violence (St. John’s: Memorial University of Newfoundland, 1995).

5 Andy Mackay, "Restorative Justice in British Columbia” Western Canadian Game Warden 2:1 (Winter 2010) 53.

6 Otto Driedger, “Restorative Justice: A Movement Gaining Momentum” SIPP Policy Dialogue 13 (Fall 2006) 20. 
development of victimology and victims' advocacy, the community-based corrections movement and efforts to rehabilitate offenders, and the work of faith communities through prison ministry and the addressing of social justice issues.

Restorative justice was developed by experimentation as community members and justice officials tried to find better ways to respond to crime in their communities. ${ }^{7}$ It has now evolved to the point that it has been called a social movement with many agendas. ${ }^{8}$ Accordingly, there is a great deal of variation in how restorative justice is defined and understood, and no single definition can encompass all of the ways in which it is practised. For the purposes of this article, restorative justice is defined as "an approach to justice that focuses on repairing the harm caused by crime while holding the offender responsible for his or her actions, by providing an opportunity for the parties directly affected by a crime victim(s), offender and community — to identify and address their needs in the aftermath of a crime." This approach emphasizes values such as "inclusion, democracy, responsibility, reparation, safety, healing, and reintegration. ${ }^{10}$ How well these values are reflected, and the extent to which victims, offenders, and community members are involved, indicate how "restorative" a process is.

\section{A. Common Restorative Justice Processes}

Just as there is a great deal of variation in defining restorative justice, there are many ways in which restorative processes operate. Ideally, these voluntary processes involve victims, offenders, and community members in discussing what happened during the offence, who has been harmed, what they need, and how the matter can be addressed. ${ }^{11}$ For victims, restorative justice provides an opportunity to talk about the harm caused and to ask questions that will assist with the healing process. For offenders, restorative justice is about taking responsibility and being held accountable for causing the harm. It also provides an opportunity for the offender to make positive changes in their life and be reintegrated into the community. For communities, it offers a way to understand the root causes of the crime, have a role in addressing the matter, and support the victim and offender.

There are four basic types of restorative justice processes in Canada: victim-offender mediation, conferences, circles, and justice committees. These processes can be adapted in many ways, depending on the types of services that the restorative justice agency provides and the needs of those involved. For example, there are many options for victim involvement.

7

Barbara Tomporowski, "Restorative Justice: A National Perspective” (Paper presented to the National Restorative Justice Symposium, St. John’s, 18 November 2009), online: Correctional Service of Canada <http://www.csc-scc.gc.ca/text/rj/rj2009/events/national/11-2009-1-eng.shtml> [Tomporowski, "Restorative Justice"].

Gerry Johnstone, "The Agendas of the Restorative Justice Movement" (Paper presented to the 2nd Restorative Practices International Conference, Vancouver, 31 May - 5 June 2009) [unpublished]. Robert B. Cormier, “Restorative Justice: Directions and Principles - Developments in Canada” (Paper presented to the 11th Session of the Commission on Crime Prevention and Criminal Justice, Vienna, 1625 April 2002), (Ottawa: Public Works and Government Services Canada, 2002) at 1.

10 Susan Sharpe, “How Large Should the Restorative Justice ‘Tent' Be?” in Howard Zehr \& Barb Toews, eds., Critical Issues in Restorative Justice (Monsey, N.Y.: Criminal Justice Press, 2004) 17 at 19.

These questions were discussed in a seminal book, which argued that there is a need to change from a retributive paradigm of justice to a restorative paradigm: Howard Zehr, Changing Lenses: A New Focus for Crime and Justice (Scottdale, Penn.: Herald Press, 1990). 
Victims may be able to participate in person, write a letter to the offender if they do not want to meet in person, or be represented by an advocate or a surrogate.

Victim-offender mediation is one of the most common processes. It involves a facilitated dialogue between a victim and an offender in which trained, impartial mediators prepare the participants to communicate in a safe and structured setting.

Conferences typically involve one or more victims and offenders who meet with a facilitator, and perhaps also with family members or other persons who can provide support. These kinds of meetings may be called "family group conferences" in cases involving young people, "community justice conferences" in cases involving adults, or "community justice forums" if the meeting uses a method taught by the Royal Canadian Mounted Police (RCMP). Some sections of the Youth Criminal Justice Act ${ }^{12}$ provide for the use of conferences in cases involving young persons. For example, s. 19(2) mandates conferences to give advice on extrajudicial measures and matters such as sentences and reintegration plans. $^{13}$

Circles go by many names, including "healing circles," "peacemaking circles," and "community circles." Circles generally involve a wider range of individuals than victimoffender mediations or conferences, with participation from families, community members, justice professionals, and others. Sentencing circles, which are perhaps the most well-known kind, may be convened by a judge to assist with crafting an appropriate sentence. ${ }^{14}$

Community and youth justice committees are widespread across Canada. ${ }^{15}$ Committees are generally comprised of volunteers who are involved in tasks such as discussing community concerns with the police and other justice agencies, working with at-risk youth, and undertaking crime prevention or public education activities. Some committees play a role in resolving adult or youth criminal matters that are referred to them through alternative measures or extrajudicial sanctions, which are discussed in the next section of this article.

As this brief discussion suggests, restorative justice can be used at many points within the criminal justice system. ${ }^{16}$ It can play a role in crime prevention by helping to identify underlying issues that are related to crime and resolving conflicts before they escalate into criminal matters. Provincial and territorial officials have indicated that most criminal matters that are handled with restorative justice are referred by police officers and Crown prosecutors on a pre-charge or post-charge basis. Moreover, judges sometimes refer cases at either the post-charge or pre-sentence stage, and may also request sentencing circles. There are also a few restorative justice programs in Canada that address serious violent offences, either presentence or post-sentence, and there have been experiments with restorative justice in

S.C. 2002, c. 1 [YCJA].

Ibid.

Austl., New South Wales Bureau of Crime Statistics and Research, Does Circle Sentencing Reduce Aboriginal Offending (Crime and Justice Bulletin No. 115) by Jacqueline Fitzgerald (Sydney: New South Wales Bureau of Crime Statistics and Research, 2008) at 1.

15 Tomporowski, "Restorative Justice," supra note 7. Ibid. 
Canadian prisons ${ }^{17}$ and in probation and parole. ${ }^{18}$ Finally, there are post-release programs, such as Circles of Support and Accountability, in which community members receive training and support from the criminal justice system to assist and supervise high-risk sex offenders who have been released into the community. ${ }^{19}$

\section{B. Restorative Justice in LAW AND Policy}

The use of restorative justice in the criminal justice system is primarily supported by provisions of the Criminal Code ${ }^{20}$ and the YCJA. ${ }^{21}$ Most of the criminal matters that are handled with restorative justice in Canada are referred under the authority of these statutes, which set out the criteria for adult alternative measures and youth extrajudicial sanctions referrals. Under s. 717(1)(b) of the Criminal Code, alternative measures may only be used if the official who makes the referral "is satisfied that [alternative measures] would be appropriate, having regard to the needs of the person alleged to have committed the offence and the interests of society and of the victim."22

The YCJA emphasizes accountability, rehabilitation, and reintegration. Section 5 sets out the objectives that apply to extrajudicial measures, including extrajudicial sanctions. Under this provision, extrajudicial measures should be designed to:

(b) encourage young persons to acknowledge and repair the harm caused to the victim and the community;

(d) provide an opportunity for victims to participate in decisions related to the measures selected and to receive reparation. ${ }^{23}$

Additionally, s. 18(2)(a) sets out the functions of youth justice committees, which may include:

(ii) supporting any victim of the alleged offence by soliciting his or her concerns and facilitating the reconciliation of the victim and the young person,

See Correctional Service of Canada, The Restorative Justice Living Unit at Grande Cache Institution: Exploring the Application of Restorative Justice in a Correctional Environment by Tania R. Petrellis (Ottawa: Correctional Service of Canada, 2007).

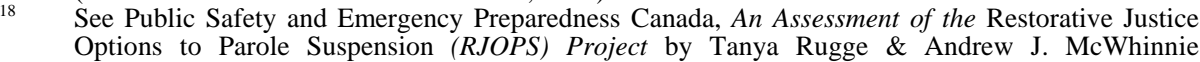
[unpublished].

19 See Susan Love, “An Eye into How CoSA Works” CoSA — Ottawa Chronicle 1:3 (August 2010) 2. R.S.C. 1985 , c. C-46.

While the Criminal Code and the YCJA are the main federal statutes that relate to the use of restorative justice, the Corrections and Conditional Release Act, S.C. 1992, c. 20, contains sections that enable Aboriginal communities to have a role in providing correctional services to Aboriginal offenders. Section 81(3) provides that offenders can be transferred into the care and custody of the community. Section 84.1(b) gives the Aboriginal community "an opportunity to propose a plan for the offender's release on supervision, and integration, into the aboriginal community." 
(iii) ensuring that community support is available to the young person by arranging for the use of services from within the community, and enlisting members of the community to provide short-term mentoring and supervision. $^{24}$

Both the Criminal Code and the YCJA state that the accused person must freely consent to participate, having been informed about the process and the right to counsel. They must accept responsibility for the act or omission that they are alleged to have committed, there must be sufficient evidence to prosecute the offence, and the prosecution must not be barred at law. ${ }^{25}$ The statutes also specify that cases may only be referred if the Attorney General of a province or territory has authorized the use of these programs. ${ }^{26}$ Federal, provincial, and territorial policies therefore play a major role in determining which cases are appropriate for referral and how cases are handled. Depending on the policies and practices in a particular jurisdiction, charges in post-charge cases may be stayed if the matter is resolved successfully. Charges may be laid in pre-charge cases or pursued in post-charge cases if the matter is not successfully resolved for some reason; for example, because the offender fails to participate.

The alternative measures provisions of the Criminal Code were part of Bill C-41: An Act to amend the Criminal Code (sentencing) and other Acts in consequence thereof, ${ }^{27}$ which was passed in 1996. Bill C-41 included a number of amendments to support community-based sentencing alternatives. ${ }^{28}$ One of these amendments was the inclusion of s. $718.2(\mathrm{e})$, which states that "all available sanctions other than imprisonment that are reasonable in the circumstances should be considered for all offenders, with particular attention to the circumstances of aboriginal offenders." ${ }^{\text {„29 }}$ This provision has been important for supporting community-based sentencing alternatives and Aboriginal justice programs. The Supreme Court of Canada upheld this provision and endorsed the concept of restorative justice in $R$. v. Gladue. ${ }^{30}$

Bill C-41 also included amendments to the sentencing principles in the Criminal Code that are consistent with restorative justice, such as promoting a sense of responsibility in offenders and encouraging them to acknowledge the harm that they caused and make reparation. ${ }^{31}$ The YCJA likewise includes objectives that are consistent with restorative justice, such as repairing harm; providing an opportunity for participation by victims in decisions about the case; and encouraging families, victims, and community members to be involved in responding to the matter. ${ }^{32}$

Ibid.

Criminal Code, supra note 20, s. 717(1); ibid., s. 10.

Criminal Code, ibid., s. 717(1)(a); YCJA, ibid., s. 10(2)(a).

1st Sess., 35th Parl., 1995 [Bill C-41].

Government of Saskatchewan, “Alternatives to Court,” online: Justice and Attorney General <http:// www.justice.gov.sk.ca/Alternatives-to-court>.

Criminal Code, supra note 20, s. 718.2(e).

[1999] 1 S.C.R. 688.

Bill C-41, supra note 27, cl. 6.

Department of Justice, “The Youth Criminal Justice Act: Summary and Background,” online: Justice Canada <http://www.justice.gc.ca/eng/pi/yj-jj/ycja-lsjpa/back-hist.html>. 


\section{The Past, Present, And Future of RESTORATIVE JUSTICE IN CANADA}

\section{A. THE EVOLUTION OF RESTORATIVE JUSTICE}

The development of victim-offender mediation was one of the earliest and most important moments in the evolution of restorative justice in Canada. This process first came about in 1974 when two teenagers went on an overnight spree of vandalism in Elmira, Ontario. The probation officer who prepared the pre-sentence report suggested to the judge that the youths should apologize to the victims. The judge agreed, and the probation officer and a community member took the two youths to meet the victims. ${ }^{33}$ This experiment became the basis for victim-offender mediation, which is now used in many countries. Community-based agencies and faith groups subsequently began offering victim-offender mediation and other kinds of restorative justice approaches in Canada in the 1970s.

One of the factors that contributed to the interest of governments and justice agencies in restorative justice was a report by the House of Commons Standing Committee on Justice and Solicitor General (Standing Committee). During a parliamentary debate in 1987 about reinstating capital punishment in Canada, the Standing Committee decided to undertake a comprehensive review of sentencing and other matters related to federal corrections. ${ }^{34}$ In its 1988 report, the Standing Committee recommended that the federal government "support the expansion and evaluation throughout Canada of victim-offender reconciliation programs at all stages of the criminal justice process," and that the sentencing principles in the Criminal Code be made more consistent with restorative justice. ${ }^{35}$ These recommendations contributed to the amendments that were enacted in Bill C-41.

In 1991, Justice Canada established the Aboriginal Justice Initiatives Pilot Program to increase the involvement of Aboriginal peoples in the administration of justice and reduce the rates of crime and victimization among Aboriginal peoples. Now called the Aboriginal Justice Strategy (AJS), the program is offered on a cost-shared basis with the provinces and territories. As of 2007-2008, the AJS supported 113 community-based programs in over 400 First Nations, Inuit, and Métis communities across Canada. ${ }^{36}$ The strategy has played an important role in supporting the development of Aboriginal justice programs, many of which use traditional justice approaches that can be consistent with restorative justice.

Several other important developments also occurred in the 1990s. Another famous Canadian experiment in restorative processes occurred in 1992, when sentencing circles were

Dean E. Peachey, “The Kitchener Experiment” in Martin Wright \& Burt Galaway, eds., Mediation and Criminal Justice: Victims, Offenders and Community (London: Sage Publications, 1989) 14 at 14-15. David Daubney, "The Role the 1987-88 Justice Committee of the House of Commons Played in Encouraging the Use of Restorative Justice in Canada” (Paper prepared for the Restorative Justice Week 2010 Basic Resource Kit, 14-21 November 2010), online: Correctional Service of Canada <http://www. csc-scc.gc.ca/text/rj/rj2010/kit/9-eng.shtml> .

35

Taking Responsibility: Report of the Standing Committee on Justice and Solicitor General on its Review of Sentencing, Conditional Release and Related Aspects of Corrections (Ottawa: Supply and Services Canada, 1988) at 97-98 (Chair: David Daubney).

36 Department of Justice, “The Aboriginal Justice Strategy,” online: Justice Canada <http://www.justice. gc.ca/eng/pi/ajs-sja/>. 
developed in the Yukon. ${ }^{37}$ Several national developments occurred later that decade, as the first National Restorative Justice Symposium was held in 1995 and National Restorative Justice Week was celebrated for the first time in $1996 . .^{38}$ Then, in 1997, the RCMP began training their officers to facilitate community justice forums, which supported the use of restorative justice in criminal matters in many provinces and territories. Yet another major step occurred in 1999, when the first National Ron Wiebe Restorative Justice Award was presented. $^{39}$

Two major events transpired in 2003. One was the introduction of the YCJA, which included the provisions for extrajudicial sanctions, conferences, and youth justice committees discussed above. The other was the development of Canadian documents entitled Values and Principles of Restorative Justice in Criminal Matters ${ }^{40}$ and Restorative Justice Program Guidelines. ${ }^{41}$ These documents flowed from work that had begun in 2000, when Canada introduced a resolution to the United Nations (UN) Commission on Crime Prevention and Criminal Justice. The resolution, which was called Basic principles on the use of restorative justice programmes in criminal matters, was adopted by the UN Economic and Social Council and the General Assembly in 2002. ${ }^{42}$ Conflict Resolution Network Canada led innovative electronic consultations on the UN document in 2002 and the Canadian texts in 2003, which indicated that there was general support for the UN resolution and the Canadian documents. ${ }^{43}$ From these early steps, the use of restorative justice has now grown to the point where there is restorative justice activity across the country. ${ }^{44}$

\section{B. The Status OF Restorative Justice In CANAdA}

Restorative justice is used to some extent in every province and territory, although the level of activity varies considerably. ${ }^{45}$ As space precludes a thorough discussion about all of the ways in which restorative justice occurs within the criminal justice system, this section provides a brief overview with some regional and national highlights.

Starting in the eastern part of the country, there are a few restorative justice initiatives in the Atlantic provinces. For example, New Brunswick is developing a framework for restorative justice and a restorative justice program has been operating for several years in an Aboriginal community. Additionally, the RCMP offers community justice forums in

Heino Lilles, "Circle Sentencing: Part of the Restorative Justice Continuum” (Paper presented to "Dreaming of a New Reality," the Third International Conference on Conferencing, Circles and other Restorative Practices, Minneapolis, Minnesota, 9 August 2002), online: International Institute for Restorative Practices <http://www.iirp.org/article_detail.php?article_id=NDQ3>. Restorative Justice Week 2009, supra note 1 at 3.

Ibid. at 25.

Department of Justice, Values and Principles of Restorative Justice in Criminal Matters (Ottawa: Department of Justice Canada, 2003), online: International Institute for Restorative Practices <http:// www.iirp.org/pdf/RJValues-DOJCan.pdf $>$.

Department of Justice, Restorative Justice Program Guidelines (Ottawa: Department of Justice Canada, 2003), online: International Institute for Restorative Practices <http://www.iirp.org/pdf/RJGuideDOJCan.pdf $>$.

ESC Res. 2002/12, UN ESCOR, 2002, Supp. No. l, UN Doc. E/2002/99.

Conflict Resolution Network Canada, Perspectives on Restorative Justice: Results of the National Consultation on Basic Principles for the Use of Restorative Justice in Canada (Waterloo: Conflict Resolution Network Canada, 2003).

Tomporowski, “Restorative Justice,” supra note 7. Ibid. 
Labrador, and Prince Edward Island uses restorative justice processes and principles in alternative measures and extrajudicial sanctions cases. Nova Scotia offers a comprehensive restorative justice strategy for youth cases that averages 1,600 youth referrals per year. ${ }^{46}$ Moreover, the results of a five-year Community University Research Alliance project about the development and implementation of restorative justice in Nova Scotia will be released in 2011.

Information provided by Quebec officials indicates that, annually, 35 percent of all youth matters in the province are handled with restorative justice. ${ }^{47}$ The province also supports alternative measures programs, community justice programs, Aboriginal justice programs, and community justice committees, which may suggest the use of mediation and circles to assist with resolving disputes involving youth and adults.

In Ontario, youth justice committees have been established in 57 court jurisdictions, and 13 agencies receive funding to provide restorative justice programs for youth. ${ }^{48}$ Additionally, the Collaborative Justice Project in Ottawa provides victim focused restorative justice services in matters involving serious offences. ${ }^{49}$

In Manitoba, the Restorative Resolutions program provides victim-offender mediation and prepares sentencing plans for adult offenders. The province has 54 designated justice committees and several Aboriginal justice projects with links to restorative justice. ${ }^{50}$ This includes the Community Holistic Circle Healing Project in Hollow Water, which uses circles and draws on restorative justice principles to respond to sexual abuse. An evaluation of the program referred to it as "restorative justice at its finest." 51

Saskatchewan handles the most adult and youth criminal matters with restorative justice in Canada: up to 6,000 referrals every year, including offences against persons and property matters. ${ }^{52}$ The province also supports an ongoing, comprehensive training program for mediators and community justice workers, and the Regina Alternative Measures Program and Saskatoon Community Mediation Services are developing projects that will handle more serious violent offences.

Alberta has 126 youth justice committees and several restorative justice agencies. The province employs an interesting model, called the Alexis Restorative Justice Court, which operates according to restorative principles and focuses on treatment, community

$46 \quad$ Ibid.

48 Barbara Tomporowski, “The Status of Restorative Justice in Canada” (Presentation to the Prairie Region Restorative Justice Gathering, Saskatoon, 26 March 2008) [unpublished] [Tomporowski, "Status of Restorative Justice”].

49 Public Safety and Emergency Preparedness Canada, Evaluation of the Collaborative Justice Project: A Restorative Justice Program for Serious Crime by Tanya Rugge, James Bonta \& Suzanne WallaceCapretta (Ottawa: Public Safety and Emergency Preparedness Canada, 2005).

Tomporowski, "Status of Restorative Justice," supra note 48 at 14.

51 Native Counselling Services of Alberta, A Cost-Benefit Analysis of Hollow Water's Community Holistic Circle Healing Process (Ottawa: Solicitor General of Canada, 2001) at 24.

52 Ministry of Justice and Attorney General of Saskatchewan, Use of Adult Alternative Measures in Saskatchewan 2004-05, 2005-06, and 2006-07 (Regina: Policy, Planning and Evaluation Branch, 2008). 
involvement, and integrated responses to offending. ${ }^{53}$ There is also an innovative partnership between the province, the Edmonton Police Service, and the Alberta Conflict Transformation Society (ACTS) in which ACTS resolves cases involving complaints by community members about the conduct of Edmonton police officers.

British Columbia has approximately 80 community-based restorative justice groups or programs and ten probation officers who operate as "Youth Justice Conferencing Specialists." The province uses restorative justice extensively on a pre-charge basis through Community Accountability Programs, which handled nearly 1,600 low-level offences (mostly property crimes) in 2007-2008. ${ }^{54}$ Furthermore, the use of restorative justice processes to address serious, violent offences such as robbery, murder, and sexual assault was pioneered by the Community Justice Initiatives Association in Langley.

Turning to the Territories, information provided by officials in Nunavut indicates that communities in that territory incorporate traditional Inuit law and perspectives into counselling and victim-offender mediation. They are also focusing on crime prevention and assisting victims and offenders with healing.

According to community justice statistics provided by the Government of the Northwest Territories, 15 percent of the territory's population participated in restorative justice activities in 2007-2008. ${ }^{55}$ These activities included community justice committee meetings and other events. In addition, there is a strong emphasis on cross-training between community justice committees, victim services, and the RCMP.

The Yukon Department of Health and Social Services administers a Youth Justice Restorative Community Conference Program. This program provides conferencing services under the YCJA and offers training in communities on restorative justice principles, practices, implementation, and facilitation. The Yukon Department of Justice is continuing to focus on integrating services to victims, offenders, families, and communities. A Victims of Crime $A c t^{56}$ is being proclaimed in the spring of 2011. The Department supports community justice committees and projects in eight communities as well as capacity development in communities through a variety of projects and approaches.

While this overview has highlighted local, provincial, and territorial initiatives, the federal government also plays an important role in restorative justice across Canada. In addition to supporting the Aboriginal Justice Strategy, Justice Canada co-chairs the Federal-ProvincialTerritorial Working Group on Restorative Justice, which is comprised of government officials who consider administrative and policy issues related to restorative justice. The department also includes the Policy Centre for Victim Issues, which supports policy development, pilot projects, and training regarding victim issues in restorative justice.

53 Alberta Justice, Alexis Restorative Justice Model: An Evaluation by Barbara Allen and BIM Larsson \& Associates (Edmonton: Alberta Justice, 2003).

54 Ministry of Public Safety and Solicitor General, Victim Services and Crime Prevention Division: Activity Report Spring 2007-Summer 2008 (Vancouver: Ministry of Public Safety and Solicitor General, 2008) at 17.

55 Tomporowski, “Status of Restorative Justice,” supra note 48 at 20. S.Y. 2010, c. 7. 
The Correctional Service of Canada has had a major impact on the evolution of restorative justice through its support for National Restorative Justice Week, the National Ron Wiebe Restorative Justice Award, and the Restorative Opportunities Program, which offers postsentence victim-offender mediation across Canada in cases involving federally sentenced offenders.

Officials with Public Safety Canada have produced several pieces of important research about restorative justice. ${ }^{57}$ The department also supports the National Demonstration Project for Circles of Support and Accountability, which will provide \$7.4 million in funding for a number of these groups across Canada over five years. ${ }^{58}$

This overview shows the tremendous richness and diversity in how restorative justice is implemented, and points to trends such as the extensive use of justice committees. Another trend is the increasing number of post-secondary courses in this field. Many colleges and universities offer classes on restorative justice, mediation, Aboriginal justice, and related topics. There are programs specifically focusing on restorative justice at the Centre for Restorative Justice in Simon Fraser University and the Queen's University School of Religion.

There is also a trend toward the establishment of formal and informal networks and associations. Such networks exist at the municipal, regional, and provincial/territorial levels, and include the Restorative Justice Network of Ottawa, the Vancouver Association for Restorative Justice, the Alberta Restorative Justice Association, and the Restorative Justice Network in Manitoba. Other communities and regions have expressed interest in developing associations, and work is occurring on the development of a national organization that is tentatively being called the Canadian Restorative Justice Consortium. ${ }^{59}$ The establishment of these groups reflects the growing number and importance of restorative justice programs in Canada.

\section{Challenges Facing Restorative Justice in CANAdA}

While restorative justice is being used across Canada, and there are signs that it is maturing, there are also a number of challenges facing restorative justice programs. These include the need for ongoing funding and national data collection, expanding the use of restorative justice in the criminal justice system, determining the relationship between Aboriginal justice and restorative justice, and engaging victims and victim serving agencies in restorative approaches.

See James Bonta et al., “Restorative Justice and Recidivism: Promises Made, Promises Kept?” in Dennis Sullivan \& Larry Tifft, eds., Handbook of Restorative Justice: A Global Perspective (New York: Routledge, 2008) 108. Another important piece of Canadian research is an article by Jeff Latimer, Craig Dowden \& Danielle Muise, "The Effectiveness of Restorative Justice Practices: A Meta-Analysis" (2005) 85 The Prison Journal 127.

58 Maristela Carrara, "CCJC's Vision of Healing through CoSA” CoSA - Ottawa Chronicle 1:3 (August 2010) 1.

$59 \quad$ Steering Committee for the Canadian Restorative Justice Consortium, Final Report on a Consultation Regarding the Potential Development of the Canadian Restorative Justice Consortium (October 2009) [unpublished] [Steering Committee, Final Report]. 
As mentioned above, the extent to which restorative justice is used varies greatly across Canada. This may be due to the circumstances in different regions and the extent to which community groups have historically been involved in responding to local issues. One of the most significant issues, however, is the lack of adequate and sustained funding experienced by many restorative justice programs. A consultation on the development of the Canadian Restorative Justice Consortium indicated that this is one of the top three concerns for restorative justice practitioners. ${ }^{60}$

The lack of comprehensive, national data collection is another major issue. Some provinces and territories have collected data on restorative justice for many years, while others are just beginning to do this, and there are differences in basic definitions and the type of information that is collected. ${ }^{61}$ As a result, it is not clear how many restorative justice programs exist across the country, how many cases are handled with restorative justice, or what the outcomes are for clients who participate in restorative processes. This makes it difficult to argue for increased funding or evaluate the impact of restorative justice on victims, offenders, and communities.

Additionally, there is a need for more research about the suitability of restorative justice for different kinds of offences. There have been ongoing concerns about whether restorative justice is appropriate in offences that involve power and gender dynamics such as sexual assault and domestic violence. ${ }^{62}$ Given the potential for revictimization, all restorative justice programs should be carefully designed with consideration for risk assessment, victim needs, and victim safety. This is even more vital if a program will address serious violent offences or offences in which power and gender are factors. Restorative programs that are considering handling such offences should work collaboratively with victims' agencies and women's organizations to ensure that these issues are considered and addressed.

Many restorative justice practitioners want to increase the number and type of criminal cases that are referred to restorative justice programs. ${ }^{63}$ Despite this, it has been suggested that restorative justice is having difficulties "making further inroads into the [criminal] justice system." ${ }^{64}$ While the lack of data makes it difficult to draw firm conclusions about the volume and kinds of matters that are referred, information from provincial and territorial government officials suggests that restorative justice tends to be used more with youth matters and property crimes. Yet there is national and international research about the positive benefits of restorative justice for victims and offenders. ${ }^{65}$ Research also indicates that restorative justice may have the most impact in reducing recidivism when it is used with violent offences. ${ }^{66}$ Increasing the number of cases that are handled with restorative justice

$60 \quad$ Ibid. at 15.

$61 \quad$ See Tomporowski, “Status of Restorative Justice,” supra note 48.

62 For a thorough discussion of this topic, see Angela Cameron, Restorative Justice: A Literature Review (Vancouver: British Columbia Institute Against Family Violence, 2005).

63 Tomporowski, “Restorative Justice,” supra note 7.

64 Steering Committee for the Canadian Restorative Justice Consortium, Restorative Justice in Canada: A Discussion Paper on the Potential Development of a Canadian Restorative Justice Consortium (November 2007) at 6 [unpublished] [Steering Committee, Discussion Paper].

65 See e.g. Latimer, Dowden \& Muise, supra note 57 at 136-38. See also Lawrence W. Sherman \& Heather Strang, Restorative Justice: The Evidence (London: Smith Institute, 2007).

66 U.K., Ministry of Justice, Does Restorative Justice Affect Reconviction?: The Fourth Report from the Evaluation of Three Schemes by Joanna Shapland et al. (London: Ministry of Justice, 2008) at 41. 
will require enhancing the capacity of community-based restorative justice agencies, including their ability to recruit staff and volunteers. Using restorative justice with more serious kinds of offences requires enhanced training for practitioners; ensuring that victims and offenders can access services such as counselling; and the support of police, Crown prosecutors, defence counsel, the judiciary, and corrections workers. It will also require the development of more programs that operate at the court, corrections, and reintegration stages of the criminal justice process.

One of the factors contributing to the relatively modest use of restorative justice in the criminal justice system is the lack of awareness among members of the public and justice officials about restorative approaches. In addition to the need for adequate funding, "low levels of public dialogue" about justice issues and "a lack of [restorative justice] input in criminal justice reform" were the top three concerns of respondents during a consultation on the Canadian Restorative Justice Consortium. ${ }^{67}$ Moreover, restorative justice is struggling for acceptance in an environment dominated by punitive rhetoric. ${ }^{68}$ Some restorative justice agencies are addressing these issues by developing media kits and communications strategies.

Concerns about "netwidening” and proportionality in sentencing might also be factors that affect the extent to which the criminal justice system has embraced restorative justice. "Netwidening" refers to the suggestion that restorative justice might be used to address relatively minor cases that previously would not have entered the criminal justice system. ${ }^{69}$ It can also mean that the offender might be subjected to a longer period of supervision in the community than they would have received with a traditional sanction. Concerns about proportionality relate to whether offenders who participate in restorative justice receive sanctions that reflect the seriousness of the crime and are similar to what they would have received if the case had gone to court. ${ }^{70}$ There is a need for research into these questions.

In addition to these issues, there is a need to consider the relationship between restorative justice and Aboriginal justice. The relationship between these two fields is contested. It has been argued that restorative justice approaches could make Aboriginal communities "responsible for meting out western forms of punishment," field has appropriated traditional Indigenous practices. ${ }^{72}$ On the other hand, initial research suggests that some Aboriginal justice programs view their traditional practices as consistent with restorative justice. ${ }^{73}$ Given the number of Aboriginal justice programs in Canada, and claims about the relationship between restorative justice and traditional Indigenous practices, this issue deserves more consideration.

Steering Committee, Final Report, supra note 59 at 15.

Steering Committee, Discussion Paper, supra note 64 at 6-7.

Lode Walgrave, “Restorative Intervention Against Juvenile Crime: Netwidening, Diversion, Sanction?” (Paper presented to the American Society of Criminology Conference, Annual Meeting, Chicago, 20-23 November 1996) [unpublished].

Cormier, supra note 9 at 14.

Dorinda M. Stahl, “Thinking Out Loud: An Overview and Critique of Past, Present and Future Forms of Restorative Justice” Justice as Healing 12:2 (2007) 1 at 6.

Steering Committee, Final Report, supra note 59 at 13-15.

Barbara Anne Tomporowski, Exploring Restorative Justice in Saskatchewan (M.A. Thesis, University of Regina, Faculty of Graduate Studies and Research, 2004), (Ottawa: Library and Archives Canada, 2005) at 27-28. 
Finally, and perhaps most importantly, there is an ongoing need to engage victims and victim serving agencies in restorative justice. The extent to which victims are welcomed and supported in restorative justice programs can vary considerably. ${ }^{74}$ While some restorative justice agencies make extensive efforts to ensure that victims feel welcome to participate and to address their needs, it is vital to ensure that all restorative justice programs are designed with consideration for victim involvement and safety.

\section{REFLECTIONS ON THE FUTURE AND CONCLUSIONS}

There is an increasing body of national and international research about restorative justice that may help to address some of the challenges discussed above. The Community University Research Alliance in Nova Scotia and the National Demonstration Project on Circles of Support and Accountability will hopefully make important contributions to the literature. Increased research may enable practitioners to answer questions about the impact of restorative justice on different groups and what constitutes "good practice." Whether there should be qualifications for restorative justice practitioners or standards for restorative justice programs is a controversial issue that may need to be addressed in the future.

Another area that warrants further attention is the link between restorative justice and transitional justice, which considers how to address systemic human rights abuses. Restorative justice has made valuable contributions in this area, and it has been argued that truth and reconciliation commissions should be built on restorative processes and principles. ${ }^{75}$ The Truth and Reconciliation Commission of Canada may provide an important opportunity for the principles of restorative justice to help address the legacy of residential schools.

This article has traced the development of restorative justice in Canada and provided an overview of how it is being used in the criminal justice sector. Restorative justice activity is occurring across the country and there are many dynamic programs. Yet there are also a number of challenges facing the restorative justice movement, such as the need for adequate and sustainable funding. Additionally, there are interrelated challenges concerning the use of restorative justice in the criminal justice system, including the need for national data collection, increased public and justice sector awareness about restorative justice, and enhancements to the capacity of restorative justice programs to handle more referrals and more serious cases. Other challenges include the need to consider the relationship between Aboriginal justice and restorative justice, and to continue engaging victims and victim service agencies in restorative approaches.

Restorative justice has come a long way since the first experiment with victim-offender mediation in 1974. Canada has some well-known programs with experience in handling serious violent offences. Formal and informal networks and associations are being

74 Barbara Tomporowski, “The Involvement of Victims in Saskatchewan’s Restorative Justice Agencies” (Paper presented to the Regina Alternative Measures Conference, 24 February 2005) [unpublished]. See e.g. Kris Vanspauwen \& Tyrone Savage, "Restorative Justice and Truth-Seeking in the DR Congo: Much Closing for Peace, Little Opening for Justice” in Ivo Aertsen et al., eds., Restoring Justice After Large-Scale Violent Conflicts: Kosovo, DR Congo and the Israeli-Palestinian Case (Cullompton, U.K.: Willan, 2008) 392. 
established. All of these factors suggest that restorative justice is maturing. The restorative justice approach is being implemented in systems unrelated to criminal justice. With continued leadership and support from community-based agencies, Aboriginal groups, faith organizations, governments, universities, and justice agencies, restorative justice will continue to evolve and expand in Canada. 